\title{
CORTES SUPREMAS E A HERANÇA BÜLOWIANA NA JURISPRUDENCIALIZAÇÃO DO DIREITO ${ }^{1}$
}

\section{SUPREME COURTS AND BÜLOWIAN'S INHERITANCE IN THE JURISPRUDENCIALIZATION OF THE LAW}

Luis Gustavo Reis Mundim Mestre em Direito Processual pela PUC/MINAS. Professor da Pós-graduação do Instituto de Educação Continuada, IECPUC/MINAS. Pós-graduado em Direito Processual pelo Instituto de Educação Continuada, IEC-PUC/MINAS. Bacharel em Direito pela PUC/MINAS. Belo Horizonte/MG. Advogado. E-mail: luis.mundim@ @reismundim.adv.br

Alexandre Varela de Oliveira Mestre em Direito Processual pela Pontifícia Universidade Católica de Minas Gerais - PUC/MINAS. Pós-graduado em Direito Público pelo Instituto para Desenvolvimento Democrático/Ius Gentium Conimbrigae (2015). Pós-graduado em Direito Processual Civil pelo Instituto para Desenvolvimento Democrático/Ius Gentium Conimbrigae (2013). Bacharel em Direito pelo Centro Universitário Newton Paiva (2011). Belo Horizonte/MG. Advogado.

RESUMO: O presente artigo objetiva apresentar que o modelo de Cortes Supremas para a formação e aplicação de precedentes é a continuidade do que é preconizado na Teoria do Processo como relação jurídica de Oskar Von Bülow, com a demonstração de sua incompatibilidade com a processualidade democrática. $\mathrm{O}$ procedimento metodológico utilizado consistiu na revisão bibliográfica acerca das cortes supremas e da processualidade democrática. Foi possível demonstrar que, no Estado Democrático de Direito, a construção

\footnotetext{
${ }^{1}$ Artigo recebido em 01/03/2019 e aprovado em 27/08/2019.
} 
e aplicação dos precedentes deve se dar em espaço processual dialógico-argumentativo a partir do referente-lógico do devido processo que irá possibilitar a compreensão dos precedentes como instituto jurídico processual na democracia, sem que haja qualquer protagonismo dos tribunais.

PALAVRA-CHAVE: Cortes Supremas. Jurisprudencialização do direito. Precedentes. Processualidade democrática.

ABSTRACT: The present article aims to present that the model of Supreme Courts for the formation and application of precedents is the continuity of what is advocated in Process Theory as a legal relationship of Oskar von Bülow, with the demonstration of its incompatibility with democratic processuality. The methodological procedure used consisted of a bibliographical review about supreme courts and democratic processuality. It was possible to demonstrate that, in the Democratic State of Law, the construction and application of precedents must take place in a dialogical-argumentative procedural space based on the logical referent of due process that will enable the understanding of precedents as a legal procedural institute in democracy, without any role of the courts.

KEY WORDS: Supreme Courts. Jurisprudencialization of the law. Precedents. Democratic Processuality. Due process.

\section{INTRODUÇÃO}

O presente trabalho possui como temática a análise do modelo das Cortes Supremas, proposto por Daniel Mitidiero, Luiz Guilherme Marinoni e Hermes Zaneti Jr., como continuidade do que foi proposto na Teoria do processo como relação jurídica de Oskar Von Bülow, na obra Lei e Magistratura, alçado ao plano dos precedentes.

Nesta perspectiva, examinou-se na primeira parte do trabalho a Teoria do processo como relação jurídica de direito público e sua pseudocientificidade, pois, conforme preconizado por Oskar Von Bülow, o processo se apresenta como um 
instrumento da jurisdição para que o julgador possa suspender a legalidade e aplicar o direito de modo solipsista, conforme sua consciência, valores e sentimentos. Assim, defende-se que os julgadores são dotados de uma sabedoria virtuosa capaz de ditar o sentido normativo para toda a sociedade.

Na segunda parte analisou-se o modelo das Cortes Supremas proposto por Daniel Mitidiero, Luiz Guilherme Marinoni e Hermes Zaneti Jr., na qual se defende que os tribunais superiores - STF e STJ -, sejam os únicos a criar uma interpretação do direito e formar precedentes para fixação do sentido normativo, com a flexibilização do princípio da legalidade. Nesse sentido, referidos autores entendem que os precedentes irão reconstruir o sentido normativo e qualquer decisão se torna justificativa para a formação de um precedente tido como obrigatório.

$\mathrm{Na}$ terceira parte foi realizado um estudo que demonstra a correlação entre a Teoria do processo como relação jurídica com o modelo das Cortes Supremas, eis que a criação do direito ainda continua a cargo do julgador, sem que as partes possam exercer os princípios constitucionais do contraditório, ampla defesa e isonomia. Analisa-se, ainda, que o modelo das Cortes Supremas gera um fechamento argumentativo e dialógico-processual, além de apresentar diversos paradoxos e aporias na formação e aplicação de precedentes obrigatórios.

Ao final, na quarta parte, expõe-se a necessidade de se conjecturar uma teoria processual dos precedentes a partir da processualidade democrática, em que ocorre a construção compartilhada das decisões estatais pela via do processo, instituição de legitimidade e implementação de direitos fundamentais a todos do povo. Somente com uma igualdade interpretativa entre Cidadão e Estado é que se torna possível a fiscalização dos precedentes e a visualização de que os tribunais superiores são tribunais constitucionalmente recursais.

Certamente não se pretendeu esgotar a temática, mas espera-se que o presente trabalho dê uma reflexão crítica

\section{LEI E MAgISTRATURA: A PSEUDOCIENTFICIDADE DA TEORIA DO PROCESSO COMO RELAÇÃO JURÍDICA DE DIREITO PÚBLICO}


Rio de Janeiro. Ano 13. Volume 20. Número 3. Setembro a Dezembro de 2019

Periódico Quadrimestral da Pós-Graduação Stricto Sensu em Direito Processual da UERJ

Patrono: José Carlos Barbosa Moreira (in mem.). ISSN 1982-7636. pp. 293-322 www.redp.uerj.br

Com o soerguimento do paradigma do Estado Social ${ }^{2}$, tanto no campo doutrinário, quanto no campo legislativo, buscou-se reestruturar o sistema processual, mediante o afastamento da visão da lógica liberal e a ampliação do papel do julgador no itinerário procedimental, passando, então, a assumir uma postura mais ativa, compensadora dos déficits de igualdade material existentes entre as partes, com a finalidade de viabilizar um julgamento mais justo, levando-se em consideração os escopos políticos, econômicos e sociais assumidos pelo processo. ${ }^{3}$

Nesse contexto paradigmático de Estado, o processo se apresentou como uma “instituição estatal de bem-estar social”, estruturado sob a técnica da oralidade, do discurso do protagonismo judicial, do princípio da imediatidade e concentração dos atos e provas, revelando-se, nitidamente, seu traço antiliberal e autoritário. ${ }^{4}$ Desse modo, sob essa concepção, "o julgador adquire maior ingerência na direção do processo, podendo, inclusive, não só realizar uma interpretação acerca do direito, mas, também efetuar sua criação, mesmo contra legem, por ser ele o guardião dos valores sociais". 5

Essa perspectiva processual contou como um de seus principais inspiradores Oskar von Bülow, no âmbito doutrinário, o qual fora considerado o inaugurador de uma linha teórica responsável por difundir a autonomia do estudo do direito processual, a partir da publicação de sua obra, em 1868, intitulada de Die lehre von den Processeinreden und die Processvoraussetzungen (Teoria das Exceções e Pressupostos Processuais). Na referida obra, Bülow buscou delinear a "tese de que haveria uma relação jurídica processual

${ }^{2} \mathrm{O}$ Estado, nessa concepção, se qualifica como "regulador e compensador das contingências políticas, sociais e econômicas, a partir de técnicas intervencionistas preventivas ou reativas, que se explicitam no âmbito das funções executivas, legislativas e judiciárias". OLIVEIRA, Marcelo Andrade Cattoni de. Direito processual constitucional. Belo Horizonte: Mandamentos, 2002, p. 59.

${ }^{3}$ Nesse contexto, apesar do alemão Oskar Von Bülow preconizar os valores econômicos, políticos e sociais do processo, foi Cândido Rangel Dinamarco, em sua obra publicada em 1987, intitulada "Instrumentalidade do Processo" quem deu continuidade à esta concepção, reforçando o discurso da centralização da jurisdição, "da defesa de uma instrumentalidade positiva, com um processo predisposta para a realização de escopos metajurídicos (sociais, políticos e econômicos) mediante a intervenção do juiz". DINAMARCO, Cândido Rangel. A instrumentalidade do processo. São Paulo: Malheiros, 2001, p. 82.

${ }^{4}$ NUNES, Dierle José Coelho. Processo jurisdicional democrático: uma análise crítica das reformas processuais. Curitiba: Juruá. 2012, p.81-83.

${ }^{5}$ VARELA, Alexandre de Oliveira. Técnica de saneamento e organização do procedimento no Código de Processo Civil de 2015. Dissertação (Mestrado). Pontifícia Universidade Católica de Minas Gerais, Programa de Pós-Graduação em Direito. Belo Horizonte, 2018, p. 18. 
Rio de Janeiro. Ano 13. Volume 20. Número 3. Setembro a Dezembro de 2019

Periódico Quadrimestral da Pós-Graduação Stricto Sensu em Direito Processual da UERJ

Patrono: José Carlos Barbosa Moreira (in mem.). ISSN 1982-7636. pp. 293-322 www.redp.uerj.br

absolutamente distinta da relação privada discutidas em juízo" ${ }^{\text {, }}$, na medida em que o processo passaria a tratar, exclusivamente, das funções dos oficiais públicos e das partes, sendo que estas apenas seriam vislumbradas como meras colaboradoras no itinerário procedimental. $^{7}$

Assim, com base nessas proposições, Bülow acreditou ser de extrema importância revisitar tudo o que já fora escrito sobre "o desenvolvimento das atividades judiciais com vistas à obtenção de decisões", utilizando-se dos pilares de uma nova ciência "destinada a tratar das características e dos contornos especialíssimos dessa relação processual". 8

Dessa forma, a construção teórica se desenvolveu a partir da preocupação terminológica que Bülow apresentou acerca da expressão "exceções processuais", pretendendo, assim, apontar que a utilização inadequada do termo pelos textos legislativos e doutrinários poderiam originar equívocos e imprecisões histórico-conceituais inaceitáveis, visto que a palavra "exceção", de origem na exceptio romana, tem como significado e alcance os "limites da argumentação de defesa do réu", guardando aproximação com a relação jurídica privada debatida entre as partes perante o magistrado e não com a relação jurídica processual. ${ }^{9}$

Deste modo, Bülow, ao discorrer sobre a relação existente entre as partes e o julgador, a qual o autor denominou de relação jurídica processual, sustentou que a verificação de eventual óbice a essa relação jurídica não estaria subordinado à apresentação de exceções pelo réu, mas, sim, caberia aos juízes e tribunais, ex officio, a atividade de analisar sua admissibilidade mediante o aferimento de certos pressupostos. ${ }^{10}$ Por tal razão,

\footnotetext{
${ }^{6}$ LEAL, André Cordeiro. Instrumentalidade do processo em crise. Belo Horizonte: Mandamentos, 2008, p. 38.

${ }^{7}$ No tocante a compreensão do processo como relação jurídica, Bülow disserta: “(...) el derecho procesal civil determina las faculdades y los deberes que ponen em mutua vinculación a las partes y al tribunal. Pero, de esa manera, se há afirmado, también, que el procesoes uma relación de derechos y obligaciones recírocas, es decir, uma relación jurídica". BÜLOW, Oscar von. Excepciones y presupuestos procesales. Buenos Aires: Europa-América, 1964, p. 01. Sobre o tema Luís Gustavo Reis Mundim discorre: "Ocorre que, apesar de Bülow não utilizar as ideias privatísticas das teorias que o antecederam, o jurista alemão importa do Direito Privado o conceito de relação jurídica. Esta perpassa pela ideia de ser um vínculo de subordinação entre duas pessoas, em que uma pode exigir um dever jurídico da outra". MUNDIM, Luís Gustavo Reis. O "Paradoxo de Bülow" no Novo Código de Processo Civil: os artigos $8^{\circ}$ e 140 como homologadores do solipsismo judicial. In: FREITAS, Sérgio Henriques Zandona; LEAL, André Cordeiro; FRATTARI, Rafhael; ENGELMANN, Wilson. (Org.). Jurisdição e técnica procedimental. Belo Horizonte: D'Plácido, 2016, p. 47.

${ }^{8}$ LEAL, André Cordeiro. Instrumentalidade do processo em crise, cit., p. 39.

${ }^{9}$ LEAL, André Cordeiro. Instrumentalidade do processo em crise, cit., p. 40.

${ }^{10}$ LEAL, André Cordeiro. Instrumentalidade do processo em crise, cit., p. 41.
} 
Bülow substituiu a expressão "exceções processuais" por "pressupostos processuais", transferindo o controle da relação jurídica processual ao julgador, qualificando-a como pública, soerguendo, assim, a autonomia do estudo do direito processual.

No entanto, foi em 1885, com a publicação de sua última obra, intitulada "Gesetz und Richteramt" (Lei e magistratura), que Oskar von Bülow deixa transparecer, de forma sistemática, sua proposta acerca da importância do papel da magistratura na interpretação, aplicação e criação do direito, além do seu consequente e necessário reforço do poder. Essa perspectiva teórica buscou enfraquecer o papel das partes e reforçar, sobremaneira, o papel dos magistrados, mediante a implementação, no campo da técnica, do protagonismo judicial, visto que o processo passou a consistir em "uma relação jurídica de direito público vinculativa das partes aos tribunais, cuja formação e existência deveria ser controlada pelos juízes". ${ }^{11}$

A partir desta perspectiva, caberia ao magistrado não só realizar o controle de toda a relação jurídica, mas, também, do próprio direito vigente, ao passo que, baseando-se nessa lógica processual, o processo se apresenta como instrumento da jurisdição, sendo essa, por sua vez, vislumbrada como atividade exercida pelo juiz na criação do direito em nome do Estado, a partir de sua cognição privilegiada, a fim de desvincular o julgador da aproximação do legalismo na aplicação do direito.

Esta perspectiva, como bem apontado por Luís Gustavo Reis Mundim, fora delineada com o fundamento em uma investida ao legalismo da Jurisprudência dos Conceitos, na medida em que, para Bülow, "não existiria solução legal para cada caso concreto" ${ }^{12}$, tornando-se, portanto, necessário reforçar o papel da magistratura, com a atribuição da incumbência pela interpretação, aplicação e criação do direito, por compreender o julgador como o tradutor avançado do sentimento jurídico do povo. ${ }^{13}$

\footnotetext{
${ }^{11}$ LEAL, André Cordeiro. Instrumentalidade do processo em crise, cit., p. 60.

${ }^{12}$ MUNDIM, Luís Gustavo Reis. O "Paradoxo de Bülow" no Novo Código de Processo Civil: os artigos $8^{\circ} \mathrm{e}$ 140 como homologadores do solipsismo judicial, cit., p. 48.

${ }^{13}$ No mesmo sentido, André Cordeiro Leal e Vinícius Lott Thibau dissertam: “A proposta bülowiana, na obra Lei e Magistratura, atacava frontalmente o legalismo, já que, segundo o autor não haveria determinação legal para cada problema concreto. Para Oskar von Bülow, diante disso, seria necessário acentuar o 'primado da vontade, do sentimento ou da intuição' dos responsáveis últimos pela interpretação, aplicação e criação atualizada do direito - os juízes”. LEAL, André Cordeiro. THIBAU, Vinicius Lott. A dogmática processual e a exceção cotidiana. Revista Brasileira de Direito Processual - RBDPro, Belo Horizonte, ano 23, n.92, p. 13- 29, out./dez.2015, p. 22.
} 
Desse modo, a partir dessa concepção teórica, autorizou-se ao julgador, na qualidade de representante do Estado, a criação do direito apoiando-se em sua própria consciência, valores e sentimentos de justiça, "como uma supra parte que possui saberes inteligíveis e transcendentais infalíveis", com a permissão de que suas decisões pudessem ir além ou até mesmo desprezar os textos legislativos, com força de lei, mesmo dela não derivando. ${ }^{14}$

Buscou-se, então, uma aplicação livre do direito e, de certa forma, subjetiva pelo julgador, visto que deveria realizar sua função com a máxima sabedoria e sensibilidade, na medida em que sua efetivação contribuiria, de sobremaneira, para o desenvolvimento e edificação do ordenamento jurídico, pois se acreditava na existência de um verdadeiro e próprio direito de origem judicial, não coincidente com o direito consuetudinário. ${ }^{15}$

O direito, então, constituía-se em um fato da experiência, que garantia ao julgador uma atuação pautada pela sua cognição privilegiada e infalível, tornando-se "intérprete da consciência popular". ${ }^{16}$ Ou seja, um porta-voz dos anseios jurídicos do povo, sendo-lhe autorizado a criação do direito mesmo contra legem, conferindo à sua decisão, apesar de contrária a norma, a característica de vinculante, pois emanada do próprio Estado e pelo ente aprovada, o que o autorizava a realizar determinações jurídicas não estabelecidas no direito pelo legislador.

Portanto, fora concedido ao julgador a criação do direito segundo sua consciência, valores e sentimentos de justiça, por lhe ter sido atribuída à incumbência de interpretar os anseios do povo, podendo, sua decisão, sob essa justificativa, ir de encontro ao próprio ordenamento jurídico. ${ }^{17}$

É o que se extrai dos dizeres de Oskar von Bülow:

\footnotetext{
${ }^{14}$ MUNDIM, Luís Gustavo Reis. O "Paradoxo de Bülow" no Novo Código de Processo Civil: os artigos $8^{\circ}$ e 140 como homologadores do solipsismo judicial, cit., p. 49.

${ }^{15}$ Sobre o tema, André Leal e Vinícius Lott Thibau lecionam: "Nota-se que o juiz, embora fosse antes tratado como mero representante do Estado instituído, passa a poder produzir decisões que o 'Estado é obrigado' (sic) e suportar e dotar com o 'selo da força jurídica'. O juiz pode proferir decisões par além da legalidade que, no entanto, recebem a força de lei, mesmo dela não derivando. O que o julgador magnânimo decide por seu desejo e por sua criação é direito, mesmo que não oriundo da legalidade e/ou ordem vigente". LEAL, André Cordeiro. THIBAU, Vinicius Lott. A dogmática processual e a exceção cotidiana, cit., p. 25.

${ }^{16}$ MADEIRA, Dhenis Cruz. Processo de conhecimento \& cognição: uma inserção no estado democrático de direito. 1. ed, 4. reimpr. Curitiba: Juruá, 2012, p. 23.

${ }^{17}$ VARELA, Alexandre de Oliveira. Técnica de saneamento e organização do procedimento no Código de Processo Civil de 2015, cit., p. 19.
} 
Então, quando acontece, várias vezes, de as decisões dos juízes contrariarem o sentido e a vontade da lei, isso deve ser aceito tranquilamente, como um destino inevitável, como um tributo, o qual os legisladores e juízes prestam à fraqueza do poder de expressão e comunicação humanas. Entretanto, nem essa consideração escusante, nem qualquer artifício jurídico, pode nos deixar desviar da verdade em questão, de que todas as muitas divergências sobre as decisões judiciais de dispositivos legais, serão, mesmo assim, confirmadas pelo poder estatal. O Estado é obrigado a suportá-las, bem como dotá-las como o selo da força jurídica. Mesmo a decisão contrária à lei possui força de lei. Ela é, como qualquer decisão judicial, uma determinação jurídica originária do Estado, validada pelo Estado e por ele provida de força de lei. Com isso, não se quer dizer outra coisa do que o juiz ser autorizado pelo Estado a realizar determinações jurídicas, as quais não estão contidas no direito legislado, mas sim encontradas pelos juízes, por eles criadas, escolhidas e desejadas. ${ }^{18}$

Assim, "o sentimento dos juízes passa a ser, então, o eixo central de legitimidade do Direito, o qual, inclusive, deve ajustar-se às determinações jurídicas por eles criadas, escolhidas e desejadas"19, em que o julgador exerce uma atividade advinda de uma "razão judicante', completiva e até mesmo supletiva da lei, posta pela consciência do julgador" que se torna "imune à crítica, porque carrega em si o atributo da certeza absoluta, que remonta ao pensamento grego do século $\mathrm{V}$ ". ${ }^{20}$

Dessa forma, "apresenta-se cognoscível que o processo passe a ser vislumbrado como uma relação jurídica de direito público vinculativa das partes ao Estado-Juiz", visto que ao julgador "se atribui o controle não só do procedimento, mas, também, de todo o direito legislado, tornando-se o protagonista do processo. ${ }^{21}$

É o que depreende das lições de André Cordeiro Leal e Vinícius Lott Thibau:

Nesse sentido, o julgador se apresenta como o titular necessário da auctoritas que garante a coerência do direito, tal como se vê, inclusive,

\footnotetext{
${ }^{18}$ BÜLOW, Oskar von. Gesetz und richtertamt. In: BÜLOW, Oskar von. Juristische zeitgeschichte - kleine reihe - kassische texte. Berlin: Berliner Wissenschafts-Verlag GmbH, 2003. v. 10, p. 37.

${ }^{19}$ TIVERON, Sérgio. A relação jurídica como técnica de suspensão da lei pelo poder do juiz e a ideologia da decisão judicial como atividade complementar da função legislativa e fonte criadora do direito ainda presentes no novo CPC - Apontamentos críticos à exposição de motivos. In: ROSSI, Fernando et al. (Coords). O futuro do processo Civil no Brasil: uma análise crítica ao projeto do novo CPC. Belo Horizonte: Fórum, 2011, p. 603.

${ }^{20}$ BATISTA, Silvio de Sá. Teoria processual da relação jurídica como técnica ideológica de julgamento: uma estagnação científica. In: BRÊTAS, Ronaldo de Carvalho Dias; SOARES, Carlos Henrique. (Coords.). Técnica processual. Belo Horizonte: Del Rey, 2015, p. 106-107.

${ }^{21}$ VARELA, Alexandre de Oliveira. Técnica de saneamento e organização do procedimento no Código de Processo Civil de 2015, cit., p. 20.
} 
nos procedimentos judiciais atuais, quando, uma vez ultrapassado o seu momento inicial, em que o juiz certifica a existência da relação processual, está ele autorizado a decidir conflitos por práticas excepcionantes. ${ }^{22}$

Percebe-se, então, que Oskar von Bülow delineia o papel do processo como um instrumento e legitimador da atividades desenvolvidas pelos julgadores, ao passo em que é encarregado por validar as pré-compreensões privilegiadas dos juízes e viabilizar a implementação, no discurso processual, da superação dos ideais do liberalismo processual, "ao partir do pressuposto publicístico (ou pseudo-publicístico, pois fruto do subjetivismo particularista dos juízes em várias hipóteses) do ativismo e protagonismo judicial”, o qual fora reforçado pela inatividade do legislador. ${ }^{23}$

Desse modo, Bülow "não se alinhara à concepção do processo como meio de controle da atividade dos juízes, mas como um instrumento de viabilização de um movimento hipoteticamente emancipatório", por intermédio da "atividade criadora do direito pela magistratura", o qual atribuiu um ilimitado poder aos julgadores. ${ }^{24}$

Conclui-se, então, que Bülow delineara uma pseudociência que se destinava, apenas e tão somente, a instrumentalizar a atividade dos julgadores, relegando à asseguração de legitimidade decisória fora do Estado Social. Portanto, sob esse viés, o autor pode apenas ser considerado como o responsável por inaugurar uma "vertente tecnológica da jurisdição como atividade do juiz", o qual se incumbiu de implementar técnicas legitimadoras da violência estatal. ${ }^{25}$

No Brasil, o Código de Processo Civil de 1973 foi diretamente influenciado pelos ideais de Bülow, que chegaram ao Brasil por meio de Enrico Tullio Liebman e, por sua vez, foram aprimoradas por Cândido Rangel Dinamarco e Alfredo Buzaid, este último sendo o responsável pela elaboração do $\mathrm{CPC} / 73$ e, também, pelo AI-5, decreto que suspendeu os direitos e garantias fundamentais do povo na ditadura militar do Brasil.

Com o advento do Código de Processo Civil de 2015, buscou-se romper com o protagonismo do julgador, já que a Constituição de 1988 alçou o processo como uma

\footnotetext{
${ }^{22}$ LEAL, André Cordeiro. THIBAU, Vinicius Lott. A dogmática processual e a exceção cotidiana, cit., p. 24.

23 NUNES, Dierle José Coelho. Processo jurisdicional democrático: uma análise crítica das reformas processuais. Curitiba: Juruá. 2012, p. 105.

${ }^{24}$ LEAL, André Cordeiro. Instrumentalidade do processo em crise, cit., p. 63.

${ }^{25}$ LEAL, André Cordeiro. Instrumentalidade do processo em crise, cit., p. 65.
} 
instituição constitucionalizada regida pelos princípios do contraditório, ampla defesa e isonomia, implementadora de direitos fundamentais.

No entanto, conforme se verá nos próximos tópicos, o tema-problema deste trabalho se apresenta quando alguns juristas passam a defender que os tribunais superiores sejam cortes supremas, sendo permitido que possam criar e interpretar livremente o direito por meio dos precedentes obrigatórios que irão vincular e serem replicados pelo judiciário a qualquer custo e sem observância do devido processo constitucional e do princípio da legalidade, o que nega a normatividade do próprio CPC/2015.

\section{CORTES SUPREMAS E PRECEDENTES OBRIGATÓRIOS}

O clamor por segurança jurídica, uniformidade jurisprudencial, celeridade e efetividade pelos tribunais brasileiros - principalmente superiores -, ainda mantém o discurso da autoridade reinante na aplicação do direito. ${ }^{26}$

A partir de tal clamor, o CPC/2015, desde a sua Exposição de $\operatorname{Motivos}^{27}$, tem supervalorizado a última palavra dos tribunais superiores como a adequada para moldar e estruturar o ordenamento jurídico, como se fossem os heróis da lacunosidade normativa e de todos anseios do povo pela rápida aplicação do direito.

Sob a justificativa de fragmentação do sistema por posicionamentos distintos dos tribunais sobre a mesma temática, a Exposição de Motivos esclarece que a função e razão de ser dos tribunais superiores seria a moldagem do ordenamento jurídico, a fim de que sua jurisprudência se torne diretriz para outros órgãos do judiciário, sendo dotada de estabilidade. $^{28}$

\footnotetext{
${ }^{26}$ Nesse sentido, importante a crítica a essa perspectiva, de que a segurança jurídica é um simulacro para o aumento de poderes nos tribunais: MUNDIM, Luís Gustavo Reis. Precedentes: da vinculação à democratização. Belo Horizonte: D’Plácido, 2018.

${ }^{27}$ Apesar da exposição de motivos estar afastada do texto final do Código de Processo Civil, suas premissas ainda têm sido aplicadas, principalmente no que tange à segurança jurídica e na verticalização da aplicação de precedentes.

28 "Em nome da segurança jurídica e da efetividade, na Exposição de Motivos do CPC/2015, é revelada a profunda preocupação com a indesejada fragmentação do sistema, algo que poderia ocorrer em decorrência da oscilação jurisprudencial. Nesse contexto, os tribunais superiores assumem a função de moldar o ordenamento jurídico por meio de suas decisões. No entanto, além dos objetivos anteriormente citados, espera-se que a uniformização e estabilização jurisprudencial, dadas não apenas pelos tribunais superiores, mas também pelos tribunais de segunda instância, sejam capazes de reduzir a sobrecarga de processos no judiciário". NUNES, Dierle; VIANA, Aurélio. Precedentes: a mutação no ônus argumentativo. Rio de Janeiro: Forense, 2018, p. 201.
} 
Rio de Janeiro. Ano 13. Volume 20. Número 3. Setembro a Dezembro de 2019

Dentro dessa perspectiva, Daniel Mitidiero, Luiz Guilherme Marinoni e Hermes

Zaneti Jr. passam a preconizar a defesa de que os Tribunais Superiores devam atuar como Cortes Supremas para a formação de precedentes obrigatórios, que irão moldar, ordenar e trazer previsibilidade ao ordenamento jurídico e à conduta do cidadão.

Para apresentar tal modelo, Daniel Mitidiero parte da exposição acerca da função das cortes superiores que se caracterizam "por pressupor, do ponto de vista da teoria do direito, a identificação entre texto, norma e regra jurídica" com a adoção "da teoria cognitivista da interpretação judicial e a assunção da declaração da norma jurídica préexistente que rege o caso concreto levado a juízo pelas partes como tarefa da jurisdição". ${ }^{29}$

Ou seja, a Corte Superior teria como objetivo controlar e aplicar a lei de modo a impor aos casos "a exata interpretação da lei" com a formação de uma jurisprudência uniforme a partir de julgados reiterados, motivo pelo qual está não seria fonte do direito. ${ }^{30}$

Em oposição às Cortes Superiores, Mitidiero apresenta as Cortes Supremas, que se caracterizam pela "dissociação entre texto e norma jurídica, o reconhecimento da normatividade dos princípios ao lado das regras, bem como a existência de postulados normativos para adequada aplicação das normas”. As Cortes Supremas, então, passariam a exercitar a atividade jurisdicional "como atividade de reconstrução da ordem jurídica mediante a outorga de sentido a textos e a elementos não textuais do sistema jurídico".31

O autor aponta, então, que o objetivo das Cortes Supremas seria o de orientar a aplicação do Direito a partir da "justa interpretação da ordem jurídica, sendo o caso concreto apenas um pretexto para que essa possa formar precedentes". O caso concreto seria, então, apenas um mecanismo para a Corte Suprema criar um precedente para vincular a sociedade e o judiciário, e se tornar fonte do direito. ${ }^{32}$

29 MITIDIERO, Daniel. Cortes superiores como cortes supremas: do controle à interpretação da jurisprudência ao precedente. 2. ed. rev. atual. e ampl. São Paulo: Revista dos Tribunais, 2014, p. 35.

30 MITIDIERO, Daniel. Cortes superiores como cortes supremas: do controle à interpretação da jurisprudência ao precedente, cit., p. 35. Ainda segundo Mitidiero, as Cortes Superiores seriam formadas por membros da carreira judiciária, controlariam a legalidade de todas as decisões a ela submetidas, com desempenho de uma função reativa, a fim de controlar a aplicação da legislação caso a caso, de modo que se coloque a exata interpretação da lei com a formação de jurisprudência uniforme. MITIDIERO, Daniel. Cortes superiores como cortes supremas: do controle à interpretação da jurisprudência ao precedente, cit., p. 35.

31 MITIDIERO, Daniel. Cortes superiores como cortes supremas: do controle à interpretação da jurisprudência ao precedente, cit., p. 55.

32 MITIDIERO, Daniel. Cortes superiores como cortes supremas: do controle à interpretação da jurisprudência ao precedente, cit., p. 55. No que tange às Cortes Supremas, Mitidiero também aponta que seriam formadas por juristas de vários extratos sociais, seriam competentes para orientar a aplicação do 
Em sua obra "Precedentes: da persuasão à vinculação", Daniel Mitidiero irá realizar um percurso histórico acerca da interpretação do direito, para demonstrar como os precedentes devem atuar pelas Cortes Supremas no direito brasileiro. Nessa esteira, argumenta que a interpretação não é pura declaração, tampouco pura criação, mas, sim, "uma reconstrução do sentido normativo, com o que não se trata nem de uma declaração de uma norma preexistente e nem de uma criação ex nihilo". As normas teriam características dúbias, ambíguas, lacunosas, motivo pelo qual deve-se reconhecer "o caráter mitológico do cognitivismo interpretativo e no reconhecimento da dupla indeterminação do direito". 33

Para enfrentar a mera declaração de norma jurídica preexistente, as Cortes Supremas se tornam fator de viabilidade da outorga de interpretação prospectiva e de unidade ao direito, motivo pelo qual a figura do precedente vinculante surge como solução a essa problemática da indeterminação do direito. Mitidiero irá argumentar, então, que tal função de Cortes Supremas, únicas capazes de criar precedentes obrigatórios, seria exercida pelo Supremo Tribunal Federal e Superior Tribunal de Justiça, com a responsabilidade de evitar a dispersão do sistema jurídico e guiar a interpretação de juízes. 34

Para Mitidiero, a autoridade do precedente passaria a estar no sentido dado ao direito pelo STF e STJ, ou seja, "a autoridade do precedente é a própria autoridade do direito interpretado e a autoridade de quem o interpreta". ${ }^{35}$ Nas palavras do autor:

A compreensão da teoria da interpretação em uma perspectiva lógicoargumentativa retira o foco exclusivamente da lei e coloca-o também no precedente, de modo que a liberdade e a igualdade a partir daí devem ser pensadas também diante do produto da interpretação e a segurança jurídica diante de um quadro que englobe tanto a atividade interpretativa como o seu resultado. Dessa forma, o precedente, sendo fruto da reconstrução do sentido da legislação, passa a ser o derradeiro garante da liberdade, da igualdade e da segurança jurídica no Estado Constitucional. Nessa linha, o precedente judicial constitui fonte primária

Direito por meio de precedentes, com atividade proativa e atuação para o futuro, além de realizar a justa interpretação da ordem jurídica. MITIDIERO, Daniel. Cortes superiores como cortes supremas: do controle à interpretação da jurisprudência ao precedente, cit., p. 55.

${ }^{33}$ MITIDIERO, Daniel. Precedentes: da persuasão à vinculação. São Paulo: Revista dos Tribunais, 2016, p.77.

${ }^{34}$ MITIDIERO, Daniel. Precedentes: da persuasão à vinculação, cit., 2016, p. 93.

${ }^{35}$ MITIDIERO, Daniel. Precedentes: da persuasão à vinculação, cit., 2016, p. 99. 
do Direito, cuja eficácia vinculante não decorre nem costume judicial e da doutrina, nem da bondade e da congruência social das razões invocadas e nem de uma norma constitucional ou legal que assim o determine, mas da força institucionalizante da interpretação jurisdicional, isto é, da força institucional da jurisdição como função básica do Estado. 36

Luiz Guilherme Marinoni, ao expor a evolução da teoria da interpretação, expõe que não mais prevalece a ideia da Revolução Francesa de que o juiz apenas reproduziria o sentido da lei, mas "fez ver que o intérprete valora e decide entre um dos resultados interpretativos possíveis". ${ }^{37}$ Para Marinoni, a norma não estaria implícita no texto legal, mas derivaria desta. Da mesma forma que Mitidiero, Marinoni aponta que "a norma, enquanto decisão judicial, é reconstruída a partir de elementos textuais e extratextuais da ordem jurídica". ${ }^{38}$

Assim, segundo o autor, a teoria da interpretação passa a depositar nas Cortes Supremas "a função de atribuir sentido ao direito (ou definir a interpretação adequada do texto legal), evidenciando a necessidade de a decisão da Corte ser legitimada por uma argumentação racional". ${ }^{39}$ A decisão passaria, então, a ocupar o lugar da justificativa das opções interpretativas, deixando de se situar na busca do sentido exato da lei, razão pela qual o direito "ganha autonomia em relação à lei". ${ }^{40}$

A partir desse posicionamento é que Marinoni defende os precedentes obrigatórios:

A decisão da Corte Suprema, ao expressar o sentido do direito, passa a orientar a vida social e a guiar as decisões dos juízes e tribunais de apelação. Se as Cortes Supremas têm a função de desenvolver o direito ao lado do legislativo, as suas decisões devem ganhar a autoridade que lhes permita corresponder ao significado que possuem na ordem jurídica. É precisamente aí que as decisões das Cortes Supremas assumem a qualidade de precedentes. ${ }^{41}$

\footnotetext{
${ }^{36}$ MITIDIERO, Daniel. Precedentes: da persuasão à vinculação, cit., 2016, p. 99.

37 MARINONI, Luiz Guilherme. A ética dos precedentes: justificativa do novo CPC. 2. ed. rev., atual. e ampl. São Paulo: Revista dos Tribunais, 2016, p. 64.

${ }^{38}$ MARINONI, Luiz Guilherme. A ética dos precedentes: justificativa do novo CPC, cit., p. 65.

${ }^{39}$ MARINONI, Luiz Guilherme. A ética dos precedentes: justificativa do novo CPC, cit., p. 65.

${ }^{40}$ MARINONI, Luiz Guilherme. A ética dos precedentes: justificativa do novo CPC, cit., p. 66.

${ }^{41}$ MARINONI, Luiz Guilherme. A ética dos precedentes: justificativa do novo CPC, cit., p. 65.
} 
Nessa esteira, para o autor, quando a Corte Suprema passa a atribuir sentido à lei e ao direito, já que possui a crença na dissociação entre texto e norma, permite-se a outorga de unidade ao direito pela via do precedente. Assim, a intepretação e o sentido dado à lei pelo precedente seriam a função da Corte Suprema, a fim de que seja possível conferir unidade ao direito. Logo, para Marinoni, o precedente passa a ser instrumento para a elaboração do significado da norma. ${ }^{42}$

Assim, Marinoni defende que as Cortes Supremas devam dar completude à atividade legislativa:

Como não resta mais qualquer dúvida de que o intérprete pode, a partir de atividades-interpretação legítimas e razoáveis, retirar mais de uma norma de um só texto legal, surge por mera consequência lógica a necessidade de conferir às Cortes de vértice a função de definir o significado atribuível à lei, sem a qual, aliás, a atividade do legislador jamais ganharia completude. Essa função, como é fácil perceber, guarda relação com a necessidade de se ter uma ordem jurídica coerente e com o respeito aos espaços de liberdade, à distribuição igualitária do direito e à segurança jurídica. É que o direito mudou de lugar; abandonou o texto legal - em que, na verdade, nunca se acomodou plenamente - e passou a ocupar o lugar das decisões das Cortes Supremas. Assim, essas, por mera consequência lógica, passaram a representar os critérios de orientação da sociedade e de solução dos casos conflitivos, dando origem ao que se chama precedente. ${ }^{43}$

Hermes Zaneti Jr. também segue a mesma linha dos autores acima. ${ }^{44}$ Segundo Zaneti Jr., a função dos Tribunais Superiores tem migrado em todos os ordenamentos jurídicos, que deixam de atuar no controle das decisões, para se preocuparem com a uniformização do direito como cortes voltadas à interpretação (Cortes Supremas). Tal migração tem ocorrido pelo fato de que todo o texto necessita de uma interpretação, segundo as contemporâneas teorias interpretativas do direito. ${ }^{45}$

Desta feita, para o autor, um ordenamento jurídico que reconheça que os Tribunais

\footnotetext{
${ }^{42}$ MARINONI, Luiz Guilherme. A ética dos precedentes: justificativa do novo CPC, cit., p. 67.

${ }^{43}$ MARINONI, Luiz Guilherme. A ética dos precedentes: justificativa do novo CPC, cit., p. 94.

44 "A teoria dos precedentes é uma teoria para Cortes Supremas. Isto quer dizer duas coisas: primeiro, que são as Cortes Supremas os principais destinatários de uma teoria dos precedentes por serem cortes de vértice e delas depender a uniformidade da interpretação do direito; segundo, porque também as Cortes Supremas devem ser vinculadas aos próprios precedentes do ponto de vista do ônus argumentativo para afastar a aplicação de um precedente ou superar um precedente antigo na aplicação atual". ZANETI JÚNIOR, Hermes. $O$ valor vinculante dos precedentes: teoria dos precedentes normativos formalmente vinculantes. 2. ed., rev. e atual. Salvador: JusPodivm, 2016, p. 291.

45 ZANETI JUNIOR, Hermes. $O$ valor vinculante dos precedentes: teoria dos precedentes normativos formalmente vinculantes, cit., p. 292.
} 
Superiores possuem um papel de Cortes Supremas, "como tribunais de vértice" é que poderá "desenvolver uma teoria adequada dos precedentes apta a atingir seus objetivos básicos (racionalidade, confiabilidade, segurança jurídica, certeza e efetividade) e suas características essenciais (universalidade, normatividade, vinculatividade, estabilidade horizontal e vertical)" ${ }^{46}$

Nas palavras do autor:

As cortes supremas se diferenciam das cortes superiores por uma série de razões. São características das cortes supremas, cortes de interpretação e precedentes, a função proativa, a nomofilaquia recursal e a unidade da interpretação do direito através dos precedentes, a igualdade perante o direito e a segurança jurídica como cognoscibilidade normativa, com eficácia para o futuro, o recurso é compreendido como ius constitutionis. 47

Desta feita, a jurisprudência torna-se "fonte primária no direito contemporâneo brasileiro", na medida em que a interpretação do direito pelos precedentes vinculantes denotaria a função criativa dos tribunais (Cortes Supremas). ${ }^{48}$

Em artigo escrito em coautoria com Carlos Frederico Bastos Pereira, Zaneti Jr. também expõem que juízes e tribunais irão se deparar com textos ambíguos e vagos, motivo pelo qual o intérprete - no caso as cortes supremas --, iriam fixar o sentido normativo:

Os juízes e juristas se depararão, na atividade jurisdicional, com textos vagos e com normas ambíguas cuja aplicação reclamará decisões interpretativas que tratem do significado da norma legal e a ela acrescentam um conteúdo reconstruído. Nos momentos em que há dúvida sobre o significado do texto normativo, o intérprete deverá decidir qual significado atribuirá ao texto. ${ }^{49}$

${ }^{46}$ ZANETI JUNIOR, Hermes. Cortes Supremas e Interpretação do direito. In: GALLOTTI, Isabel. et all. $O$ Papel da jurisprudência do STJ. São Paulo: Revista dos Tribunais, 2014, p.178.

${ }^{47}$ ZANETI, JÚNIOR. Hermes. Cortes Supremas e Interpretação do direito, cit., p.178.

${ }^{48}$ ZANETI JÚNIOR, Hermes. A constitucionalização do processo: o modelo constitucional da justiça brasileira e as relações entre processo e constituição. 2. ed. rev., ampl., alterada. São Paulo: Atlas, 2014, p. 233 e 241.

${ }^{49}$ ZANETI JÚNIOR, Hermes. PEREIRA, Carlos Frederico Bastos. Por que o poder judiciário não legisla no modelo de precedentes do Código de Processo Civil de 2015? In: Revista de Processo. vol. 257/2016. P. 371 - 388. Jul/2016, p. 374. 
No entanto, conforme se verá, o modelo das Cortes Supremas acaba por manter aquilo que Bülow preconizava, de que juízes e tribunais seriam os intérpretes finais do direito a partir da flexibilização da lei, vindo a criar o direito a partir da atividade jurisdicional. Essa perspectiva aplicada aos precedentes acaba por gerir uma jurisprudencialização do direito autoritária e agressiva aos direitos e garantias fundamentais.

\section{A HERANÇA BÜLOWIANA E A JURISPRUDENCIALIZAÇÃO DO DIREITO NO CPC/2015: UM FANTASMA QUE AINDA ASSOMBRA}

Conforme visto, Bülow defendia que a interpretação do direito não poderia se reter ao formalismo da lei, motivo pelo qual o juiz estaria autorizado a decidir conforme sua consciência, valores e sua discricionariedade.

Da mesma forma, Mitidiero, Marinoni e Zaneti Jr. entendem que o formalismo da lei é insuficiente para o julgamento dos casos concretos quando defendem que a indeterminação do direito, a partir dos vazios e ambiguidades advindos da legislação, comprometem a sua aplicação, motivo pelo qual depositam nos precedentes e nas Cortes Supremas a fé de que irão dar a correta interpretação à lei.

Assim, da mesma forma que Bülow enfrenta o mero legalismo, os referidos precedentalistas também o fazem quando preconizam que os precedentes serão a solução para a indeterminação do direito, já que entendem e pressupõem que a lei não possui sentido a priori. Nessa esteira, importante pontuar que os autores confundem a noção de legalismo e legalidade, o que acaba por gerar ainda mais poderes aos tribunais superiores (cortes supremas).

Vale mencionar que o legalismo é a mera reprodução da lei, enquanto o princípio da legalidade é balizado pelas garantias constitucionais do processo. Nesse sentido, Ulisses Dalle, com base em Ronaldo Brêtas expõe que a legalidade atua:

[...] como o dever, constitucionalmente imposto ao juiz, de observar e fazer cumprir o ordenamento jurídico, e, em especial, os direitos e garantias fundamentais, de modo que a integração do direito se dê não por usos e costumes, pela sensibilidade, livre consciência ou senso pessoal de justiça do julgador, mas pelo embate argumentativo apto a 
maximizar a efetividade dos princípios e garantias constitucionais, mediante técnica de interpretação das normas jurídicas em conformidade com os preceitos constitucionais. ${ }^{50}$

Assim, ao permitirem que o Superior Tribunal de Justiça e o Supremo Tribunal Federal passem a atuar como Cortes Supremas, Mitidiero, Marinoni e Zaneti Jr. apenas repetem aquilo que Bülow preconizava em 1885 em "Lei e Magistratura" no plano dos Tribunais Superiores. ${ }^{51}$ Confia-se no sentimento e na consciência dos tribunais superiores, como se os seus julgadores fossem receptores e captadores dos valores e anseios sociais, com qualificação para saber o que é melhor ou pior para o povo. ${ }^{52} \mathrm{E}$ essa situação torna-se ainda mais devastadora, pois tanto STJ e STF têm decidido não só contra a lei e a Constituição, mas apesar da lei e da Constituiçãoo. ${ }^{53}$

Conforme se percebe, a teoria do processo como relação jurídica continua a ecoar na doutrina e até mesmo no modo com que o Código de Processo Civil tem sido interpretado. Efetivamente, referida teoria é um lobo disfarçado de cordeiro a atacar, a qualquer momento, todos os ganhos democráticos advindos da referida legislação.

A defesa dos precedentes obrigatórios - a partir das cortes supremas - certamente nega a normatividade fundamental que o CPC tanto abarca e tenta implementar, pois deixa à margem qualquer participação das partes, juízes e tribunais inferiores de construírem provimentos vinculantes.

${ }^{50}$ DALLE, Ulisses Moura. Técnica processual e imparcialidade do juiz. In: BRÊTAS, Ronaldo de Carvalho Dias. SOARES, Carlos Henrique. (Coord.). Técnica processual. Belo Horizonte: Del Rey, 2015, p.74. Conferir, também: BRÊTAS, Ronaldo de Carvalho Dias. Processo constitucional e estado democrático de direito. 3. ed. rev. e ampl. Belo Horizonte: Del Rey, 2015, p.158-164.

${ }^{51}$ No mesmo sentido, é o pensamento de Lenio Streck: "Interessante é que os mesmos que defendem o commonlismo são os que sempre apostaram no protagonismo judicial. É o fantasma de Oskar Büllow arrastando suas correntes pelos castelos jurídicos". STRECK, Lenio Luiz. Precedentes judiciais e hermenêutica: o sentido da vinculação no CPC/2015. Salvador: JusPodivm, 2018, p. 18.

${ }^{52}$ Nessa perspectiva, o judiciário acaba por se tornar o superego da sociedade, não só em capturar os anseios sociais, mas "ensinar a um povo 'doente' um sentimento 'sadio' - é justamente nisso que consiste sua função de superego". MAUS, Ingeborg. O judiciário como Superego da Sociedade. Rio de Janeiro: Lumen Juris, 2010, p. 33.

${ }^{53}$ Lenio Streck, em obra que procura apontar as falhas das teses precedentalistas das Cortes Supremas, faz interessante indagação a Daniel Mitidiero: "se é verdade que os precedentes encarnam o próprio significado da Constituição e das leis, então podemos afirmar que é o precedente que dá significado à Constituição e às leis? Mas, e se a interpretação da Corte Suprema acerca da Constituição estiver equivocada? E quando a Corte Suprema diz qualquer coisa? É o próprio Mitidiero quem diz que o precedente deve ser 'aplicado' [sic] ainda que o órgão responsável pela aplicação o veja como errado. De novo: auctoritas nos veritas facit precedente. Repergunto: não é um modelo de precedente rígido? Pareceme bastante óbvio que sim. Nitidamente parece legitimar uma livre atribuição de sentido por parte das Cortes Supremas. Que o próprio Mitidiero reconhece como falíveis". STRECK, Lenio Luiz. Precedentes judiciais e hermenêutica: o sentido da vinculação no CPC/2015, cit., p. 132-133. 
É essa patologia ${ }^{54}$ de índole solipsista, em que o Eu (paranoico) cria e diz o que é o direito, mesmo fora da lei e apesar da lei, que tem (conta)minado a possibilidade de uma construção e aplicação dos precedentes a partir de um espaço processual participativo, dialógico, discursivo e fiscalizatório entre todos os sujeitos processuais.

Mitidiero, Marinoni e Zaneti Jr., ao acreditarem que os precedentes são normas prontas e acabadas, geram um totalitarismo hermenêutico que apenas é replicado por técnicas de aceleração de procedimentos ${ }^{55}$ por um judiciário que não interpreta e não permite interpretar os precedentes a partir do devido processo legal e de um procedimento de conhecimento regido pelo contraditório, ampla defesa e isonomia.

Há aqui um fechamento argumentativo tamanho que proporciona uma violência normativa desmanteladora das garantias processuais e que acabam por gerar uma jurisprudencialização do direito ${ }^{56}$. Esse fechamento argumentativo é criticado por Luís Gustavo Reis Mundim:

Isso porque, a defesa dos Tribunais Superiores, STF e STJ, como Cortes Supremas, é apostar as cartas em uma jurisdição salvífica solipsista, voltada ao sincretismo das violências fundadoras e conservadoras do direito (Estado-Segurança-Exceção), que impõem suas decisões autoritariamente em um edifício de ponta-cabeça.

A busca por um fundamento soberano e único pelas Cortes Supremas gera um fechamento argumentativo que ignora por completo as premissas de igualdade interpretativa (hermenêutica isomênica) que devem haver entre Cidadão e Estado na democracia, pois coloca este último em uma posição de vantagem que reduz qualquer possibilidade de exercício de crítica científica pelo medium do devido processo.

Ora, esse discurso autoritário por uma crença irredutível nos fundamentos místicos (e míticos) da autoridade das Cortes Supremas e da autoridade do próprio precedente, acaba por camuflar e gerar um enorme vácuo normativo (espaço nu - desprocessualizado) reinado pela razão

${ }^{54}$ A palavra patologia também é utilizada aqui para denunciar a denominada patologia ou complexo de Magnaud, que foi um juiz francês arbitrário e autoritário, que não se vinculava à lei e aplicava o direito conforme seus sentimentos, sua consciência e seu livre arbítrio. Para tanto, conferir: BRÊTAS, Ronaldo de Carvalho Dias. Processo constitucional e estado democrático de direito, cit., p. 160.

${ }^{55}$ Como exemplo de tais técnicas ritualísticas há a tutela de evidência, a improcedência liminar do pedido, o julgamento monocrático da apelação. Referidos autores precedentalistas preconizam, ainda, uma inconstitucional ampliação do rol de aplicação de decisões vinculantes por tais técnicas, o que demonstra o caráter utilitarista de tal tese. Para uma crítica a tal perspectiva, que fere o processo de conhecimento, conferir: MUNDIM, Luís Gustavo Reis. Precedentes: da vinculação à democratização, cit., p. 202-214.

${ }^{56}$ FARIA, Gustavo de Castro. Jurisprudencialização do direito: reflexões no contexto da processualidade democrática. Belo Horizonte: Arraes, 2012. 
Rio de Janeiro. Ano 13. Volume 20. Número 3. Setembro a Dezembro de 2019

Periódico Quadrimestral da Pós-Graduação Stricto Sensu em Direito Processual da UERJ

Patrono: José Carlos Barbosa Moreira (in mem.). ISSN 1982-7636. pp. 293-322 www.redp.uerj.br

jurisprudencial que impede qualquer discursividade das partes na construção dos provimentos vinculantes. ${ }^{57}$

O modelo das Cortes Supremas "nos cria um modelo ultraestatalista que se autolegitima e esvazia o papel da cidadania, o que não se pode aceitar num Estado democrático de Direito"58, já que não considera os direitos e garantias processuais constitucionais para balizar a formação e aplicação dos precedentes.

Importante mencionar, ainda, que a defesa das Cortes Supremas possui diversos paradoxos, que acabam por gerar mais aporias e falhas.

O primeiro é a continuidade do paradoxo de Bülow, consistente no problema de que o processo é um instrumento da jurisdição para a livre criação do direito pelo juiz e, ao mesmo tempo, seu mecanismo de controle. ${ }^{59}$

Nessa esteira, pertinente o questionamento de Luís Gustavo Reis Mundim, ao transpor referida crítica ao modelo das Cortes Supremas, já que a defesa dos precedentalistas é a de que as Cortes Supremas atuariam como seu próprio controle, o que acaba por elevar o paradoxo bülowiano à seara dos precedentes vinculantes:

São essas amarras do espectro da segurança jurídica (violência normativa) que mantém um enorme paradoxo na criação de precedentes vinculantes, pois como é possível que as Cortes Supremas se "autogovernem" sendo que possuem poderes ilimitados para gerar precedentes a partir de qualquer decisão? Como pode a atividade jurisdicional criar o direito de modo solipsista e ser o próprio controle dessa atividade criativa das Cortes Supremas? ${ }^{60}$

Além do paradoxo de Bülow, Carlos Henrique Soares aponta quatro paradoxos dos precedentes obrigatórios, quais sejam, a eficiência na prestação jurisdicional, a razoável duração do processo, a segurança jurídica e o devido processo. Segundo o autor, a

\footnotetext{
${ }^{57}$ MUNDIM, Luís Gustavo Reis. Precedentes: da vinculação à democratização, cit., p. 187.

${ }^{58}$ NUNES, Dierle. PEDRON, Flávio Quinaud. HORTA, André Frederico Sena. Os precedentes judiciais, o art. 926 do CPC e suas propostas de fundamentação: um diálogo com concepções contrastantes. In: Revista de Processo. Vol. 263/2017, p. 335 - 396, Jan. 2017, p.23.

${ }^{59}$ LEAL, André Cordeiro. A instrumentalidade do processo em crise, cit., p. 65. MUNDIM, Luís Gustavo Reis. O "Paradoxo de Bülow" no Novo Código de Processo Civil: os artigos $8^{\circ}$ e 140 como homologadores do solipsismo judicial, cit., p.51-53. TIVERON, Sérgio. A relação jurídica como técnica de suspensão da lei pelo poder do juiz e a ideologia da decisão judicial como atividade complementar da função legislativa e fonte criadora do direito ainda presentes no novo CPC - Apontamentos críticos à exposição de motivos, p. 602.

${ }^{60}$ MUNDIM, Luís Gustavo Reis. Precedentes: da vinculação à democratização, cit., p. 189-190.
} 
crença nos precedentes vinculantes para que proporcionem eficiência, razoável duração do processo, celeridade, segurança jurídica e efetivação do devido processo não passam de uma utopia, pois ao final acabam por ampliar os poderes dos tribunais, ferir as garantias constitucionais do contraditório, da ampla defesa e da isonomia, e camuflar o real problema da prestação jurisdicional, que são as etapas mortas do procedimento. ${ }^{61}$

Acresce-se, ainda, o paradoxo dos precedentes obrigatórios, o qual se mostra no momento em que qualquer sujeito processual, dentre eles juízes e tribunais inferiores, podem interpretar a ratio decidendi e dar sentido ao precedente. É o que apontam Aurélio Viana e Dierle Nunes:

Se as cortes e os juízes de grau inferior podem interpretar a ratio decidendi, por conseguinte poderão também divergir em relação ao próprio precedente, uma vez que o seu núcleo é exatamente a ratio. Se a ratio decidendi não é vinculante, não há como o precedente sê-lo. Reside nisso o paradoxo! Como falar em precedente obrigatório se o seu núcleo - a ratio decidendi - encontra-se em estado de permanente abertura à interpretação pelas cortes inferiores? É de significativa relevância lembrar que cabe ao juiz do caso sucessivo estabelecer a existência ou não de precedente. ${ }^{62}$

Como se percebe, o modelo das Cortes Supremas apenas se preocupa com a criação de teses gerais e abstratas para aplicação em casos futuros, em perspectiva neoliberal e utilitarista, apenas para acabar com o número de recursos e processos nos tribunais. Concordamos, então, com Lenio Steck, no sentido de que não será "a delegação da adjudicação de sentido para Cortes de Vértice que resolveremos o problema" ${ }^{63}$ já que esse aumento de poderes dos tribunais superiores gera uma pretensa funcionalidade que "é a sua própria disfuncionalidade". 64

Portanto, o que se pode inferir é que o modelo das Cortes Supremas implementa uma jurisprudencialização do direito totalitária e arbitrária ao fechar qualquer espaço processual de discursividade pelos sujeitos processuais, com observância ao contraditório,

\footnotetext{
${ }^{61}$ SOARES, Carlos Henrique. Paradoxos dos precedentes judiciais. Revista Brasileira de Direito Processual RBDPro, Belo Horizonte, ano 25, n. 100, p. 55-83, out./dez. 2017.

${ }^{62}$ NUNES, Dierle; VIANA, Aurélio. Precedentes: a mutação no ônus argumentativo, cit., p. 257.

${ }^{63}$ STRECK, Lenio Luiz. Precedentes judiciais e hermenêutica: o sentido da vinculação no CPC/2015, cit., p. 18.

${ }^{64}$ STRECK, Lenio Luiz. Precedentes judiciais e hermenêutica: o sentido da vinculação no CPC/2015, cit., p. 20.
} 
à ampla defesa e à isonomia. Trata-se de uma perspectiva extremamente paradoxal $^{65}$ que não consegue enxergar e responder às suas próprias aporias (vazios) e que falha em efetivar a constitucionalidade democrática.

Essa crença acaba por camuflar a herança bülowiana nos precedentes que nutre superpoderes aos tribunais superiores e nega a normatividade constitucional e fundamental da processualidade democrática.

\section{A TEORIA PROCESSUAL DOS PRECENDENTES: O NECESSÁRIO ROMPIMENTO COM O AUTORITARISMO JURISPRUDENCIAL}

Pela exposição acima, torna-se crucial romper com a perspectiva bülowiana de processo, a fim de que haja uma teoria processual dos precedentes desvinculada de tal paradoxo e que permita a participação, o diálogo e a fiscalidade/controle da atividade jurisdicional na formação e aplicação de precedentes.

Para tanto, necessário adotar como premissa teorias processuais que estejam em consonância com a perspectiva de que o processo não é mais um instrumento da jurisdição para a paz social, em que juízes e tribunais estariam a utilizar os escopos metajurídicos como critérios para decisão ${ }^{66}$. Na verdade, não compreendemos a dificuldade e relutância em se superar a perspectiva processual bülowiana ainda tão aclamada, visto que, com o advento do paradigma jurídico-constitucional do Estado Democrático de Direito, delineouse uma nova concepção acerca do processo, concepção esta democratizante, asseguradora da fiscalização, participação e do controle do povo sobre todas as atividades desempenhadas pelo Estado, por intermédio de uma estrutura técnico-normativa, em respeito e observância à soberania popular e aos direitos fundamentais.

À vista disso, o processo, em sua perspectiva democratizante, denota-se como "base e mecanismo de aplicação e controle de um direito democrático"67, no qual se permite a

\footnotetext{
65 Sobre diversos outros paradoxos e falhas acerca do modelo das Cortes Supremas, conferir: STRECK, Lenio Luiz. Precedentes judiciais e hermenêutica: o sentido da vinculação no CPC/2015, cit.

${ }^{66}$ Sobre uma análise acerca das teorias do processo em perspectiva crítica, conferir: VARELA, Alexandre de Oliveira. MUNDIM, Luís Gustavo Reis. Teorias do processo e processualidade democrática: incursões pelo racionalismo crítico. In: FREITAS, André Vicente Leite de; DINIZ, Fernanda Paula. (Org.). Estudos avançados em Direito. Rio de Janeiro: Lumen Juris, 2017, p. 3-21, v. 01.

67 NUNES, Dierle José Coelho. Processo jurisdicional democrático: uma análise crítica das reformas processuais, p.81-83.
} 
institucionalização de estrutura normativa que viabilize e efetive, de fato, a participação, fiscalização/controle dos destinatários dos efeitos da decisão na construção do pronunciamento estatal, alçando-o como centro das garantias constitucionais, em virtude de sua atribuição de assegurar a concretização dos direitos fundamentais.

Percebe-se, assim, a relevância técnica e legitimadora do processo, visto que busca concretizar balizas discursivas indispensáveis para o efetivo debate comparticipativo entre os sujeitos processuais, elevando a argumentação a um primeiro plano, afastando-se a perspectiva de protagonismo, em razão da imposição de uma compreensão da interdependência entre os sujeitos processuais. ${ }^{68}$ Desse modo, a concretização de um regime comparticipativo, viabiliza a todos os sujeitos a possibilidade de uma interlocução ativa, ao passo em que estabelece, como uma de suas premissas norteadoras, a realização de um diálogo profícuo a ser desenvolvido em todo o itinerário procedimental, permitindo com que possam participar, em igualdade de condições, na condução do processo, visando a construção de um pronunciamento jurisdicional decisório fundamentado na principiologia do Estado Democrático de Direito.

Nesse ínterim, a perspectiva democrática do processo retira do decisor a compreensão de sujeito soberano da estrutura técnico-normativa, eis que, no paradigma jurídico-constitucional do Estado Democrático de Direito, não se elege um intérprete da consciência popular"69 e, "tampouco, permite formação de decisões lastreadas em privilégios cognitivos do magistrado"70, na medida em que estas passam ser compreendidas como "o resultado lógico da atividade procedimental desenvolvida em torno das questões discutidas e dos argumentos produzidos em contraditório pelas parte em todas as fases do processo", cujas "as razões de justificação (argumentos), das partes, envolvendo as razões da discussão (questões), produzidas em contraditório, constituirão base para as razões da decisão", sendo esta “ a essência do dever de fundamentação, permitindo a geração de um pronunciamento participado e democrático". ${ }^{71}$

${ }^{68}$ VARELA, Alexandre de Oliveira. Técnica de saneamento e organização do procedimento no Código de Processo Civil de 2015, cit. p. 28.

${ }^{69}$ MADEIRA, Dhenis Cruz. Processo de Conhecimento \& Cognição: Uma inserção no Estado Democrático de Direito, p. 23.

${ }^{70}$ VARELA, Alexandre de Oliveira. Técnica de saneamento e organização do procedimento no Código de Processo Civil de 2015, cit. p. 101.

${ }^{71}$ BRÊTAS, Ronaldo de Carvalho Dias. Processo constitucional e estado democrático de direito, p. 136. 
Dessa forma, é possível concluir que a legitimidade e racionalidade do pronunciamento jurisdicional estão atreladas ao compartilhamento processual, de maneira que se concretizam mediante o fluxo discursivo exercido pelos sujeitos dentro da estrutura técnico-normativa $^{72}$, ou seja, não poderá ser fruto do arbítrio ou discricionariedade do julgador, mas, sim, resultante da análise de todas as questões debatidas endoprocessualmente.

Assim, o processo, enquanto instituição de participação e fiscalização/controle, "deve ter alicerce nas bases democráticas conferidas ao devido processo, não mais extraídas de uma sociedade civil pressuposta em que a autoridade conduziria o sentido normativo", mas, sim, pela "autoinclusão de todos na construção, aplicação e extinção de direitos fundamentais constitucionalmente assegurados"73, mediante a observância obrigatória do princípio da legalidade, da procedimentalidade, da ampla defesa, contraditório, isonomia e fundamentação das decisões jurisdicionais.

Portanto, não mais podemos sustentar uma perspectiva processual com bases socializadoras, como aquela apresentada por Bülow, visto que o processo passa a ser compreendido como uma estrutura técnico-normativa garantidora de aplicação e exercício de direitos fundamentais, mediante a efetiva fiscalização/controle, participação e debate endoprocessual realizado para construção dos pronunciamentos jurisdicionais, afastando, desse modo, a concepção do solipsimo decisional.

Isto posto, é com base nessas premissas que devemos sustentar uma teoria processual dos precedentes desgarrada do modelo das Cortes Supremas, visto que esta última perspectiva autoriza a autolegitimação dos tribunais e permite o esvaziamento o papel da cidadania, relegando a um segundo plano os direitos e garantias fundamentais do processo, além de olvidar por completo da principiologia do paradigma jurídicoconstitucional do Estado Democrático de Direito.

$\mathrm{Na}$ processualidade democrática, não podem os tribunais superiores serem vislumbrados como eixos legitimadores do direito, visto que, apenas, mediante a estrutura normativa constitucionalizada que se garante um adequada fruição dos direitos fundamentais “em visão normativa, além de uma ampla comparticipação e

\footnotetext{
${ }^{72}$ MADEIRA, Dhenis Cruz. Processo de Conhecimento \& Cognição: Uma inserção no Estado Democrático de Direito, p. 117.

${ }^{73}$ MUNDIM, Luís Gustavo Reis. Precedentes: da vinculação à democratização, p. 117.
} 
problematização, na ótica policêntrica do sistema, de todos os argumentos relevantes para os interessados" "74, possibilitando a construção dos pronunciamentos jurisdicionais a partir do fluxo discursivo exercido endoprocessualmente. Assim, o processo não se torna apenas "referente paradigmático de aferição de legitimidade decisória, mas um critério da própria jurisdicionalidade". ${ }^{75}$

É nesse sentido que Luís Gustavo Reis Mundim assevera que na perspectiva da "processualidade democrática não é possível que apenas e tão somente um tribunal superior diga qual o sentido correto das normas pela via de um precedente, sob pena de torná-lo não físcalizável e abrir margem aos solipsismos dos julgadores"76, visto que acabam por fechar argumentativamente a construção dos precedentes, inviabilizando a realização de um profícuo debate processualizado em sua formação e aplicação.

Percebe-se, então, que no discurso democrático não há condições para que se possibilite o aparecimento de um espaço do soberano, ou seja, um espaço não fiscalizável em que se atribui à autoridade o encargo de enunciar o sentido normativo contido no texto da lei, eis que, nesta perspectiva, os destinatários da norma jurídica são plenamente capazes de realizar uma adequada interpretação. "Por isto, o atual paradigma constitucional exige que a decisão judicial seja construída, de forma compartilhada e não mais de forma solitária pelo julgador", ao passo em que, na democracia, o decisor “não julga sozinho, não é uma supraparte, não pode ser um sujeito solipsista que impõe sua posição subjetiva aos demais". 77

Nesse sentido, Rosemiro Pereira Leal leciona:

O que se põe em relevância à compreensão do instituto do precedente é o afastamento do primado da jurisdição que caracteriza o Estado Dogmático (Liberal e Social de Direito) para, em seu lugar, instituir o devido processo como centro do sistema jurídico de Estado Democrático, exigindo sempre, à formação jurisprudencial por cadeia de precedentes, a ser uniformizada, na construção das decisões, o crivo construtivo do

74 NUNES, Dierle José Coelho. Processo jurisdicional democrático: uma análise crítica das reformas processuais, p. 250.

${ }^{75}$ LEAL, André Cordeiro. Instrumentalidade do processo em crise, p. 152. Sobre "jurisdicionalidade", André Cordeiro Leal disserta: O termo jurisdicionalidade para o autor "passa a ter como critério referencial, não a atividade do julgador, mas o grau de legitimidade decisória a partir do princípio do discurso". LEAL, André Cordeiro. Instrumentalidade do processo em crise, p. 151.

${ }^{76}$ MUNDIM, Luís Gustavo Reis. Precedentes: da vinculação à democratização, p. 188.

77 MADEIRA, Dhenis Cruz. Argumentação jurídica: (in)compatibilidade entre a tópica e o processo. Curitiba: Juruá. 2014, p.344. 
devido processo legal, que é o conjunto de procedimentos processualizados à consolidação da 'segurança jurídica, liberdade e igualdade' (tão solicitadas pelos jurisdicionalistas!) como direito fundamental constitucionalizado no Brasil (art. $5^{\circ}$, LIV e LV, da CF/88). Nos Estados Democráticos, não é a atividade jurisdicional per se que vai promover a tão almejada unidade do direito por uma fundamentação secundum conscientiam (cognitivismo interpretativo do positivismo lógico), mas uma fundamentação egressa da cognitividade objetiva das estruturas lógico-discursivas da procedimentalidade processualizada que legitima a construtividade dos precedentes no âmbito de uma decisão jurídica, não mais de uma instrumental de-cisão judicial a partir de uma razão performativa do saber jurisdicional. ${ }^{78}$

Desse modo, os tribunais não podem atuar de forma solitária e, tampouco, suas interpretações acerca do texto legal serem alçadas a categoria de norma jurídica, na medida em que o ordenamento jurídico terá legitimidade quando as decisões proferidas forem consequência do compartilhamento processual, sem que os atributos dos julgadores se tornem referência para sua construção, privilegiando-se a principiologia do processo estruturado sob as premissas Estado Democrático de Direito. Sendo assim, os tribunais não terão como atribuição a determinação solipsista do sentido normativo, visto que lhe é vedado, na processualidade democrática, obstar com que os sujeitos processuais atuem efetivamente na interpretação da lei e do precedente, devendo, portanto, fomentar um profícuo discurso processual democrático, afastando a criação de espaços do soberano.

Nessa esteira, o modelo das Cortes Supremas, ainda arraigada na perspectiva bülowiana de processo, é inaplicável à constitucionalidade democrática, eis que os tribunais superiores não possuem a função de serem criadores de normas-precedentes obrigatórios já que possuem função recursal, conforme leciona Rosemiro Pereira Leal:

Do exposto e em se ressaltando que o Brasil não tem 'Supremas Cortes', mas tribunais recursais, uma vez que nossos STF e STJ não podem, em paradigma de Estado Democrático (Estado não Dogmático), atuar pela judicialização da política na qualidade de guardiães míticos (tutores, mentores) de um sacratíssimo livro constitucional brasileiro, como apregoam os seus próprios ministros em sua excelsa e estranha nomenclatura, o instituto processual do precedente adotado pelo $\$ 2^{\circ}$ do art. 926 do $\mathrm{CPC} / 2015$ há de ser dimensionado (semanticamente demarcado) a partir da intrassignificatividade normativa posta pelo caput do art. 926 e seu $\S 1^{\circ}$ a estabelecer o seguinte e novo roteiro configurativo

${ }^{78}$ LEAL, Rosemiro Pereira. A questão dos precedentes e o devido processo. Revista Brasileira de Direito Processual-RBDPro, Belo Horizonte, ano 25, n. 98, p. 295 -313, abr./ju.2017, p. 305. 
da formação e uniformização da jurisprudência no Brasil a fim de, reduzindo seus erros e fracassos históricos, torná-la 'estável, íntegra e coerente' $[\ldots]^{79}$

Nesse espeque, além da observância da principiologia constitucional e institutiva do processo, para se ter uma teoria processual dos precedentes, torna-se crucial que estes estejam vinculados não pela autoridade, mas pela causa de pedir e pedido, ao processo de conhecimento balizado pelo devido processo, à possibilidade de discussão, superação e distinção, a fim de que o povo - sujeito constitucional -, exerça o devido controle e fiscalidade de tal instituto processual. ${ }^{80}$

Assim, a construção e aplicação dos precedentes não podem ocorrer dentro de um espaço desprocessualizado, eis que a norma resultante do precedente não é consequência da atividade intelectiva do julgador, mas, sim, fruto de uma dialogicidade exercida dentro de uma estrutura técnica normativa regida pelo contraditório, ampla defesa, isonomia e fundamentação das decisões, princípios institutivos estes que acarretam em sua legitimação, eis que em consonância com a constitucionalidade democrática.

Portanto, concluímos que, efetivamente, uma teoria dos precedentes em consonância com a processualidade democrática "só é possível no espaço processual (espaço normatizado), eis que é apenas neste ambiente que qualquer do povo consegue ficar em pé de igualdade com as funções e decisões do Estado, a fim de usar o devido processo como instituição legítima de correição". ${ }^{81}$

\section{CONCLUSÃO}

Ante ao que foi exposto, observa-se que a proposta das Cortes Supremas nada mais é do que uma herança da fantasmagórica Teoria do processo como relação jurídica de Oskar Von Bülow, em que juízes e tribunais legitimam o direito por seus próprios sentimentos e transformam o processo em um locus de violência normativa.

Para tanto, demonstrou-se que a Teoria do processo como relação jurídica teve um caráter pseudocientífico, pois em "Lei e Magistratutra" Bülow delineia uma perspectiva de

\footnotetext{
${ }^{79}$ LEAL, Rosemiro Pereira. A questão dos precedentes e o devido processo, cit., p. 306-307.

${ }^{80}$ Para maior aprofundamento de tais elementos, conferir: MUNDIM, Luís Gustavo Reis. Precedentes: da vinculação à democratização, p. 215-255.

${ }^{81}$ DEL NEGRI, André. O avesso do Estado. Belo Horizonte: D’Plácido, 2018, p. 201.
} 
que o juiz assume o protagonismo e o monopólio decisório, o que transforma o processo em um mero instrumento da jurisdição. Nessa esteira, a jurisdição se destina apenas a instrumentalizar a atividade criativa e discricionária dos julgadores, em que a implementação de direitos fundamentais é ignorada para legitimar técnicas de uma violência estatal normativa.

Com o advento do Código de Processo Civil de 2015 e com a incorporação dos precedentes, a doutrina passa a propor um modelo de Cortes Supremas, em que o Superior Tribunal de Justiça e Supremo Tribunal Federal passem a reconstruir o sentido normativo pela via dos precedentes obrigatórios. Em razão da indeterminação do direito e das ambiguidades da legislação, defende-se a flexibilização da legalidade para atribuição do sentido normativo e a outorga de unidade ao direito pela via do procedente obrigatório gerado pela Corte Suprema.

No entanto, por se tratar de uma perspectiva que ignora as premissas fundamentais da processualidade democrática, o modelo das Cortes Supremas apenas legitima aquilo que Oskar Von Bülow preconizou, elevando ao plano dos precedentes a violência normativa pelo solipsismo dos tribunais. As premissas bülowianas, alinhadas ao modelo das Cortes Supremas, acabam por gerar diversos paradoxos e a impossibilidade de exercício de controle e fiscalidade dos pronunciamentos decisórios pelo povo, o que impossibilita uma construção e aplicação de precedentes a partir dos princípios do contraditório, da ampla defesa e da isonomia.

Assim, crucial a construção de uma teoria processual dos precedentes desraigada de premissas estatalistas e que leve em consideração a legitimidade decisória, a participação das partes, a influência e a fiscalidade das decisões, a fim de que o processo como instituição constitucionalizada gere um espaço dialógico-processual de construção compartilhada dos precedentes. Os tribunais superiores, então, não possuem função de formar precedentes ilimitados, mas, sim, são tribunais recursais, conforme previsto na Constituição, já que devem estar em plano de igualdade interpretativa com o Cidadão.

Conclui-se que é necessário o rompimento definitivo com a letargia dogmática da Teoria do processo como relação jurídica, eis que insuficiente para efetivar direitos fundamentais a partir do processo constitucional-democrático e para a construção de uma teoria processual dos precedentes como instituto jurídico-processual. 


\section{REFERENCIAS}

BATISTA, Silvio de Sá. Teoria processual da relação jurídica como técnica ideológica de julgamento: uma estagnação científica. In: BRÊTAS, Ronaldo de Carvalho Dias; SOARES, Carlos Henrique. (Coords.). Técnica processual. Belo Horizonte: Del Rey, 2015 .

BRÊTAS, Ronaldo de Carvalho Dias. Processo constitucional e estado democrático de direito. 3. ed. rev. e ampl. Belo Horizonte: Del Rey, 2015.

BÜLOW, Oscar von. Excepciones y presupuestos procesales. Buenos Aires: EuropaAmérica, 1964.

BÜLOW, Oskar von. Gesetz und richtertamt. In: BÜLOW, Oskar von. Juristische zeitgeschichte - kleine reihe - kassische texte. Berlin: Berliner Wissenschafts-Verlag GmbH, 2003. v. 10.

DALLE, Ulisses Moura. Técnica processual e imparcialidade do juiz. In: BRÊTAS, Ronaldo de Carvalho Dias. SOARES, Carlos Henrique. (Coord.). Técnica processual. Belo Horizonte: Del Rey, 2015.

DEL NEGRI, André. O avesso do Estado. Belo Horizonte: D’Plácido, 2018.

DINAMARCO, Cândido Rangel. A instrumentalidade do processo. São Paulo: Malheiros, 2001.

FARIA, Gustavo de Castro. Jurisprudencialização do direito: reflexões no contexto da processualidade democrática. Belo Horizonte: Arraes, 2012.

LEAL, André Cordeiro. Instrumentalidade do processo em crise. Belo Horizonte: Mandamentos, 2008.

LEAL, André Cordeiro. THIBAU, Vinicius Lott. A dogmática processual e a exceção cotidiana. Revista Brasileira de Direito Processual - RBDPro, Belo Horizonte, ano 23, n.92, p. 13- 29, out./dez.2015.

LEAL, Rosemiro Pereira. A questão dos precedentes e o devido processo. Revista Brasileira de Direito Processual - RBDPro. Belo Horizonte, ano 25, n. 98, p. 295 313, abr./ju.2017. 
MADEIRA, Dhenis Cruz. Argumentação jurídica: (in)compatibilidade entre a tópica e o processo. Curitiba: Juruá. 2014.

MADEIRA, Dhenis Cruz. Processo de conhecimento \& cognição: uma inserção no estado democrático de direito. 1. ed, 4. reimpr. Curitiba: Juruá, 2012.

MARINONI, Luiz Guilherme. A ética dos precedentes: justificativa do novo CPC. 2. ed. rev., atual. e ampl. São Paulo: Revista dos Tribunais, 2016.

MAUS, Ingeborg. O judiciário como Superego da Sociedade. Rio de Janeiro: Lumen Juris, 2010 .

MITIDIERO, Daniel. Cortes superiores como cortes supremas: do controle à interpretação da jurisprudência ao precedente. 2. ed. rev. atual. e ampl. São Paulo: Revista dos Tribunais, 2014.

MITIDIERO, Daniel. Precedentes: da persuasão à vinculação. São Paulo: Revista dos Tribunais, 2016.

MUNDIM, Luís Gustavo Reis. O "Paradoxo de Bülow" no Novo Código de Processo Civil: os artigos $8^{\circ}$ e 140 como homologadores do solipsismo judicial. In: FREITAS, Sérgio Henriques Zandona; LEAL, André Cordeiro; FRATTARI, Rafhael; ENGELMANN Wilson. (Org.). Jurisdição e Técnica Procedimental. Belo Horizonte: D'Plácido, 2016.

MUNDIM, Luís Gustavo Reis. Precedentes: da vinculação à democratização. Belo Horizonte: D’Plácido, 2018.

NUNES, Dierle José Coelho. Processo jurisdicional democrático: uma análise crítica das reformas processuais. Curitiba: Juruá. 2012.

NUNES, Dierle. PEDRON, Flávio Quinaud. HORTA, André Frederico Sena. Os precedentes judiciais, o art. 926 do CPC e suas propostas de fundamentação: um diálogo com concepções contrastantes. In: Revista de Processo. Vol. 263/2017, p. 335 - 396, Jan. 2017.

NUNES, Dierle; VIANA, Aurélio. Precedentes: a mutação no ônus argumentativo. Rio de Janeiro: Forense, 2018.

OLIVEIRA, Marcelo Andrade Cattoni de. Direito processual constitucional. Belo Horizonte: Mandamentos, 2002. 
SOARES, Carlos Henrique. Paradoxos dos precedentes judiciais. Revista Brasileira de Direito Processual - RBDPro, Belo Horizonte, ano 25, n. 100, p. 55-83, out./dez. 2017.

STRECK, Lenio Luiz. Precedentes judiciais e hermenêutica: o sentido da vinculação no CPC/2015. Salvador: JusPodivm, 2018.

TIVERON, Sérgio. A relação jurídica como técnica de suspensão da lei pelo poder do juiz e a ideologia da decisão judicial como atividade complementar da função legislativa e fonte criadora do direito ainda presentes no novo CPC - Apontamentos críticos à exposição de motivos. In: ROSSI, Fernando et al. (Coords). O futuro do processo Civil no Brasil: uma análise crítica ao projeto do novo CPC. Belo Horizonte: Fórum, 2011.

VARELA, Alexandre de Oliveira. Técnica de saneamento e organização do procedimento no Código de Processo Civil de 2015. Dissertação (Mestrado). Pontifícia Universidade Católica de Minas Gerais, Programa de Pós-Graduação em Direito. Belo Horizonte, 2018.

VARELA, Alexandre de Oliveira. MUNDIM, Luís Gustavo Reis. Teorias do processo e processualidade democrática: incursões pelo racionalismo crítico. In: FREITAS, André Vicente Leite de; DINIZ, Fernanda Paula. (Org.). Estudos avançados em Direito. Rio de Janeiro: Lumen Juris, 2017, p. 3-21, v. 01.

ZANETI JÚNIOR, Hermes. A constitucionalização do processo: o modelo constitucional da justiça brasileira e as relações entre processo e constituição. 2. ed. rev., ampl., alterada. São Paulo: Atlas, 2014.

ZANETI JÚNIOR, Hermes. Cortes Supremas e Interpretação do direito. In: GALLOTTI, Isabel. Et all. O Papel da jurisprudência do STJ. São Paulo: Revista dos Tribunais, 2014

ZANETI JÚNIOR, Hermes. O valor vinculante dos precedentes: teoria dos precedentes normativos formalmente vinculantes. 2. ed., rev. e atual. Salvador: JusPodivm, 2016.

ZANETI JÚNIOR, Hermes. PEREIRA, Carlos Frederico Bastos. Por que o poder judiciário não legisla no modelo de precedentes do Código de Processo Civil de 2015? In: Revista de Processo. vol. 257/2016. P. 371 - 388. Jul/2016. 